\title{
Study on Quality and Abundance of Zooplankton in Surface Offshore Waters of Southern Part of Caspian Sea
}

\author{
Reza Rahnama $^{1, *}\left(\mathbb{D}\right.$, Ali Hamzehpour ${ }^{1}$ \\ ${ }^{1}$ Iranian National Institute for Oceanography and Atmospheric Science (INIOAS). No. 3, Etemadzadeh St., Fatemi Ave., \\ Tehran, 1411813389, IR Iran.
}

\section{Article History}

Received 10 June 2019

Accepted 26 November 2019

First Online 12 December 2019

\section{Corresponding Author}

Tel.: +989116706619

E-mail: rezam_bio79@yahoo.com

\section{Keywords \\ Plankton \\ Cladocera \\ Copepod \\ Diversity \\ Abundance}

\begin{abstract}
In this study diversity and abundance of zooplankton in south Caspian Sea offshore waters were investigated. During the first season of oceanographic cruise in winter 2014 at southern part of Caspian Sea, 8 stations at offshore waters of south Caspian Sea were selected. Totally, 4 Holopelankton and 6 meroplankton were identified. Among the identified zooplanktonic groups, Copepods were the main zooplanktonic group that constituted about $53 \%$ of total abundance and $65 \%$ of total biomass. They were dominant in all stations. Predominant species of copepods was Acartia tonsa. Its abundance was between $\left(106 \pm 42\right.$ ind. $\left.\mathrm{m}^{-3}\right)$ and $\left(1545 \pm 181\right.$ ind. $\left.\mathrm{m}^{-3}\right)$. After $A$. tonsa, lamellibranch larvae had the highest abundance in all stations (18\%) and fish larvae was at second place in terms of biomass (27\%). Results showed after invasion of $M$. leidyi, composition and abundance of zooplankton in south Caspian Sea waters greatly changed.
\end{abstract}

\section{Introduction}

Caspian Sea is the biggest land-locked saltwater lake in the world with a catchment area of 3.5 million $\mathrm{km}^{2}$ (Mamaev, 2002). It is located between $36^{\circ} \mathrm{N}$ and $62^{\circ} \mathrm{N}$. The basin of Caspian Sea is divided into three distinct physical regions: Northern, Middle, and Southern Caspian. The northern Caspian that only include the Caspian shelf is very shallow and accounts less than $1 \%$ of the total water volume. The middle Caspian accounts $33 \%$ of the total water volume. The southern Caspian is the deepest with oceanic depths of over $1000 \mathrm{~m}$ and accounts $66 \%$ of the total water volume. (Kosarev and Yablonskaya, 1994; Aladin and Plotnikov, 2004). Environmental conditions in the Caspian Sea has significantly changed under the impact of human activities and has been significantly altered during the past 30 years, apart from natural changes attributable largely to sea level variability (Rodionov, 1994). Anthropogenic pollution is a significant threat on the biodiversity of the Caspian Sea (Salmanov, 1999; Aladin and Plotnikov, 2004). Impacts on the ecosystem notably are from domestic pollutants including various detergents, industrial pollutants especially the heavy metals and agricultural pollutants, in particular nutrients owing to over fertilization and pesticides. The faunal composition of Caspian Sea has changed totally during last decades because of its water level fluctuations, human manipulation and the entry of an alien invasive species of a Ctenophore jellyfish. During 80s Mnemiopsis leidyi (originated from the north Atlantic waters) was transferred to the Black Sea, Azof, Marmara and east Mediterranean Seas and then to Caspian Sea (Shiganova, 1993; Dumont, 1995; Shiganova et al., 2001; Fuentes et al., 2010). Zooplankton are recognized among the best indicators to be particularly useful to 
investigate and document environmental changes (Sipkay et al., 2009). Major zooplankton taxa have short life cycle and the community structure is able to reflect real-time scenario as it is less enforced by the stability of individuals from previous years (Richardson, 2008). Zooplankton community structure serves as a critical trophic link between the lower and higher trophic levels. They represent a highly diverse and complex plankton group, participating in water circulation and energy having strong metabolic activity. Through the direct ingestion of phytoplankton, zooplankton influence population and species dynamics; through excretion and secretion, they contribute to the decomposition and circulation of organic matter in aquatic ecosystems and stimulate algae growth. Zooplanktons are the prey for fish and other aquatic animals, they play an important role in aquatic ecosystems (Guangjun, 2013). There are no documents on diversity and abundance of zooplanktons in south Caspian Sea's offshore waters. Most of the studies focus on investigating the composition and abundance of zooplankton in near shore waters. Most of the studies on zooplankton in south Caspian Sea water were carried out by Iranian Fisheries Research Organization (IFRO). Several studies have been undertaken regarding the zooplankton communities and their structures alongside Iranian coasts in the southern parts of the Caspian Sea in recent years such as: (Rowshantabari, 2000; Laloei et al., 2004; Hashemian et al., 2006; Hosseini et al., 2011; bagheri et al., 2013; Rowshantabari et al, 2014; Pourang et al., 2016 and etc...). No study has been done on the community of zooplankton in the offshore water of south Caspian Sea. Furthermore, regarding to the effects of alien species invasion (M. leidyi) in Caspian Sea, studying the structure and biomass of zooplankton in the offshore water of south Caspian Sea has high importance.

\section{Material and Methods}

The study was carried out in offshore water of south Caspian Sea (Figure 1). One transects with 8 stations were selected (Table 1). The distance among sampling stations was $30 \mathrm{~km}$. Sampling was conducted in winter season (April 2014). Samples were collected in both day and night [ 7 stations at day and in 1 station $\left(\mathrm{S}_{5}\right)$ at night].

Samples were collected by zooplankton net (100 $\mu \mathrm{m}$ mesh with a $0.36 \mathrm{~m}$ mouth diameter) by vertical hauling from $10 \mathrm{~m}$ depth. After collecting, specimens were preserved in a $4 \%$ formaldehyde seawater solution. In the laboratory samples were studied in a Bogarov tray contained $0.5 \mathrm{ml}$ of each sample (Postel et al., 2000). Biomass of zooplankton was estimated from the shape of each species (Petipa, 1957) and an invert microscope was used for identifying them. Zooplankton taxonomic classification was performed based on (Birshtein et al., 1968; Kusmorskaya, 1964; Kuticova, 1970). Biomass and abundance data were calculated as per cubic meter. Zooplankton distribution type was determined based on formula below:

$$
A=\frac{\text { var }}{\text { ave }}
$$

Where $A$ indicates distribution index, Var variance of identified zooplankton and Ave average of identified zooplankton abundance. If $(A<A v e)$, distribution will be uniform and if ( $A>A v e)$, distribution will be spotty and if $(A=A v e)$, it will be randomly.

During collection of samples on shipboard, physical and chemical parameters of sea water including temperature, salinity, $\mathrm{pH}$ and dissolved oxygen (DO) were measured by using multimeter portable devices

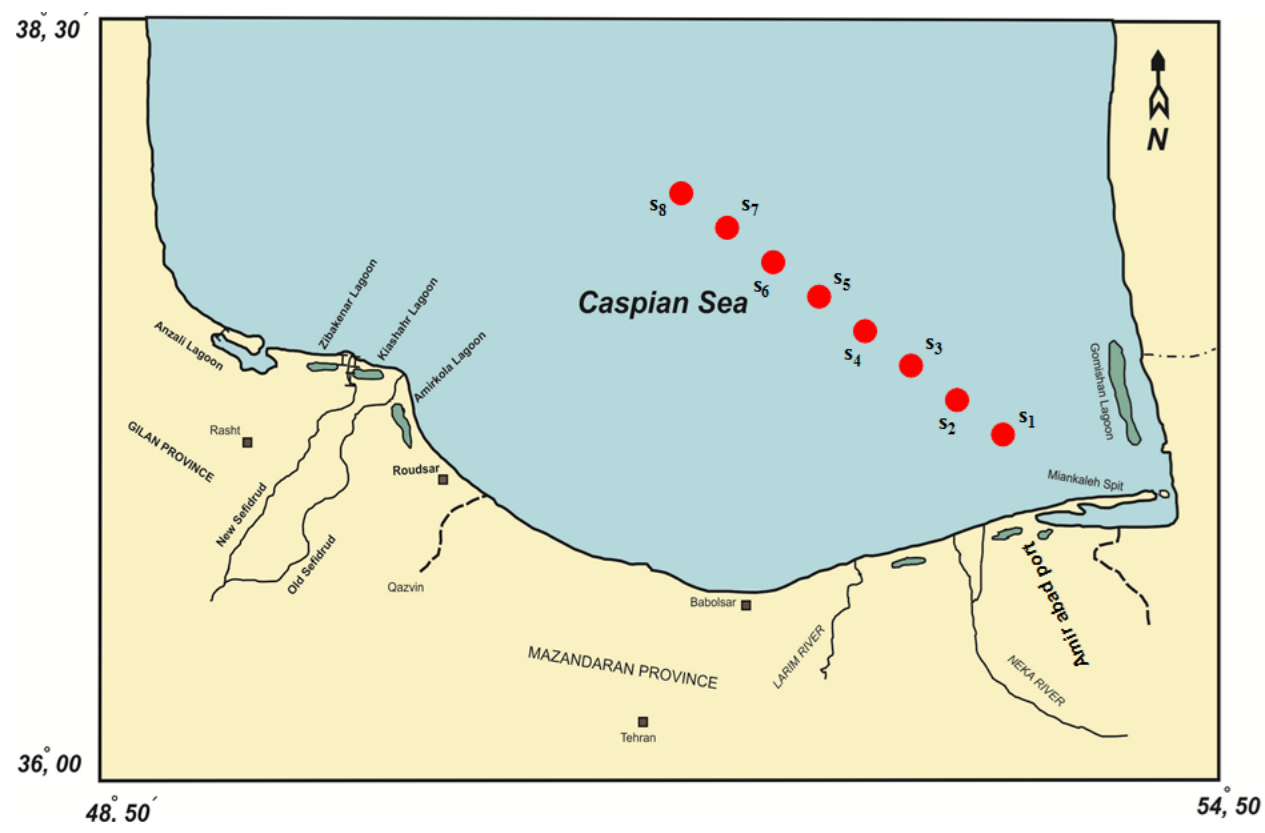

Figure 1. Map of sampling stations in the south Caspian Sea waters. 
Table 1. Position of sampling stations in offshore waters of south Caspian Sea

\begin{tabular}{ccc} 
Station & Position & Depth $(\mathrm{m})$ \\
\hline $\mathrm{S}_{1}$ & $37 \mathrm{~N} 02.671$ & 250 \\
& $53 \mathrm{E} 03.256$ & \\
$\mathrm{~S}_{2}$ & $37 \mathrm{~N} 16.866$ & 480 \\
& $52 \mathrm{E} 44.678$ & \\
$\mathrm{~S}_{3}$ & $37 \mathrm{~N} 31.005$ & 510 \\
& $52 \mathrm{E} 26.299$ & \\
$\mathrm{~S}_{4}$ & $37 \mathrm{~N} 44.441$ & \\
& $52 \mathrm{E} 09.086$ & \\
$\mathrm{~S}_{5}$ & $37 \mathrm{~N} 58.549$ & \\
& $51 \mathrm{E} 50.483$ & \\
$\mathrm{~S}_{6}$ & $38 \mathrm{~N} 09.947$ & 722 \\
& $51 \mathrm{E} 27.394$ & \\
$\mathrm{~S}_{7}$ & $38 \mathrm{~N} 20.452$ & 735 \\
& $51 \mathrm{E} 12.822$ & \\
$\mathrm{~S}_{8}$ & $38 \mathrm{~N} 20.033$ & 750
\end{tabular}

(Hach, HQ 40d). Water samples were filtered through membrane filter of $47 \mathrm{~mm}$ diameter and $0.45 \mu \mathrm{m}$ pore size and kept frozen at $-20^{\circ} \mathrm{C}$ for analysis of nitrate $\left(\mathrm{NO}_{3}{ }^{-}\right.$ ), nitrite $\left(\mathrm{NO}_{2}{ }^{-}\right)$, phosphate $\left(\mathrm{PO}_{4}{ }^{3-}\right)$ and silicate $\left(\mathrm{H}_{3} \mathrm{SiO}_{4}{ }^{-}\right)$. Analyses were done according to the standard methodology (APHA, 1985).

\section{Statistical Analysis}

Statistical analyses were carried out by using SPSS software (SPSS ver. 16) and PAST program (ver. 2.09b). One-way analysis of variance (ANOVA) was used to test the differences among the abundance of zooplanktons in different stations. Tukey's test $(P<0.05)$ was used to assess the significant differences among the stations. The relationship between abundance of zooplanktons and physico-chemical parameters in different stations was estimated by using a Pearson's rank correlation coefficient and Principal components analysis (PCA) $(P<0.05)$. According to environmental conditions similarity among stations was calculated using the BrayCurtis coefficient after transforming data by the $\log X$.

\section{Results}

Physico-chemical parameters of sea water are shown in (Figure 2). The range of salinity was from $\left(12.52 \mathrm{~g} . \mathrm{Kg}^{-1}\right)$ at station 1 to $\left(12.87 \mathrm{~g} . ~ K g^{-1}\right)$ at station 3 . Maximum temperature was $\left(13.80^{\circ} \mathrm{C}\right)$ at station 4 and minimum was $\left(11.70^{\circ} \mathrm{C}\right)$ at station 3 . Station 7 had the highest value of $\mathrm{pH}(8.67)$ and the lowest was found at station 4 (8.60). DO values were found maximum and minimum (10.54 and $\left.9.97 \mathrm{mg} . \mathrm{L}^{-1}\right)$ at stations 7 and 4, respectively. Figure 3 shows nutrients concentration in all stations. Nitrite concentration only measured at station $1\left(2.13 \mu \mathrm{g} . \mathrm{L}^{-1}\right)$ and it was not detectable in the other stations. The highest concentration of nitrate was found at station $3\left(42.05 \mu \mathrm{g}\right.$. $\left.\mathrm{L}^{-1}\right)$ and the lowest was at station $1\left(4.28 \mu \mathrm{g}\right.$. $\left.\mathrm{L}^{-1}\right)$. Also, the range of silicate concentration was between $12 \mu \mathrm{g}$. $\mathrm{L}^{-1}$ at station 1 and $156 \mu \mathrm{g}$. $\mathrm{L}^{-1}$ at station 4 . In all stations, concentration of phosphate was not detectable. Based on the cluster analysis, all stations were divided in two main groups; group A contained the station with the lowest concentrations of all abiotic parameters measured. On the other hand, group B contained two subgroups: $B_{1}$ contained three stations with high concentration of silicate. $B_{2}$ contained four stations with medium concentration of silicate (Figure 4). Both axes from the Principal Components Analysis (PCA) explained $66 \%$ of the total variance. In component 1 , most positive correlation was found among salinity, silicate and nitrate, being negatively correlated to the nitrite. In component 2, most positive correlation was found between $\mathrm{DO}$ and $\mathrm{pH}$ (Figure 5), having negative correlation with temperature. Dispersal of stations may be explained by nitrate and silicate concentrations. In this study a total number 4 Holoplankton and 6 meroplankton were identified, including: Acartia tonsa and Nauplius of A. tonsa; Copepoda - Asplanchna priodonta; Rotifera - Podon polyphemoides; Cladocera Larvae of Nereis diversicolor; Nereididae - Cypris, nauplius and cirrus stages of Balanus improvises; Cirripedia - Lamellibranch larvae;bivalvia and Fish larvae.

Table 2 shows the average abundance of the identified zooplanktons in each of the 8 stations. As shown, Acartia tonsa has the highest abundance at station $5\left(1545 \pm 181\right.$ ind. $\left.\mathrm{m}^{-3}\right)$ followed by Nauplis of $A$. tonsa $(1168 \pm 232$ ind.m-3) at the same station. The lowest abundance belongs to Cypris of Balanus improvisus $\left(64 \pm 22\right.$ ind. $\left.\mathrm{m}^{-3}\right)$ at station 4 . Among all 


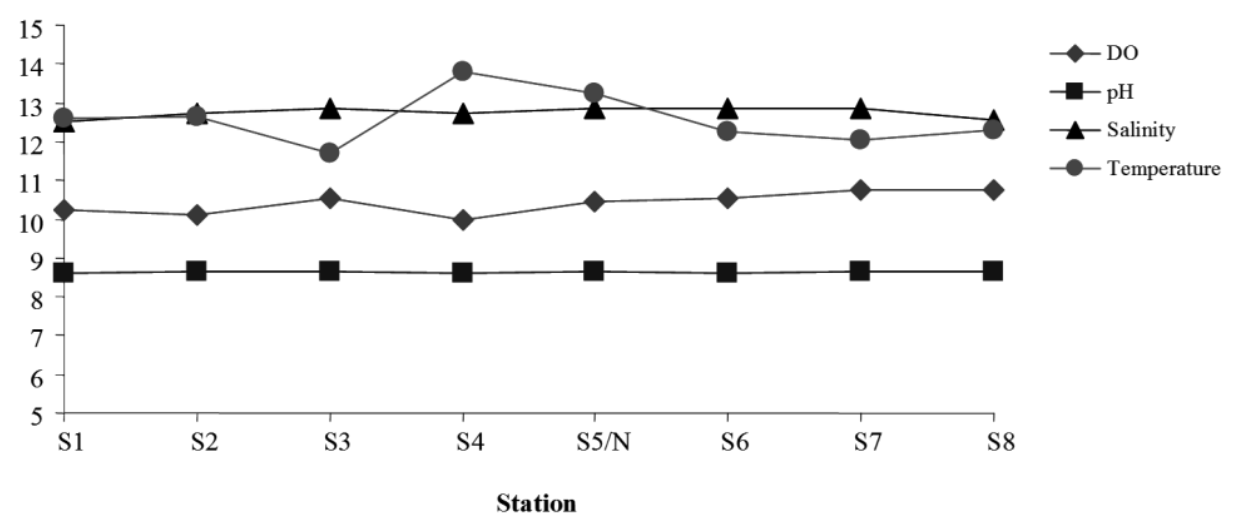

Figure 2. Physico-chemical parameters measured in all stations.

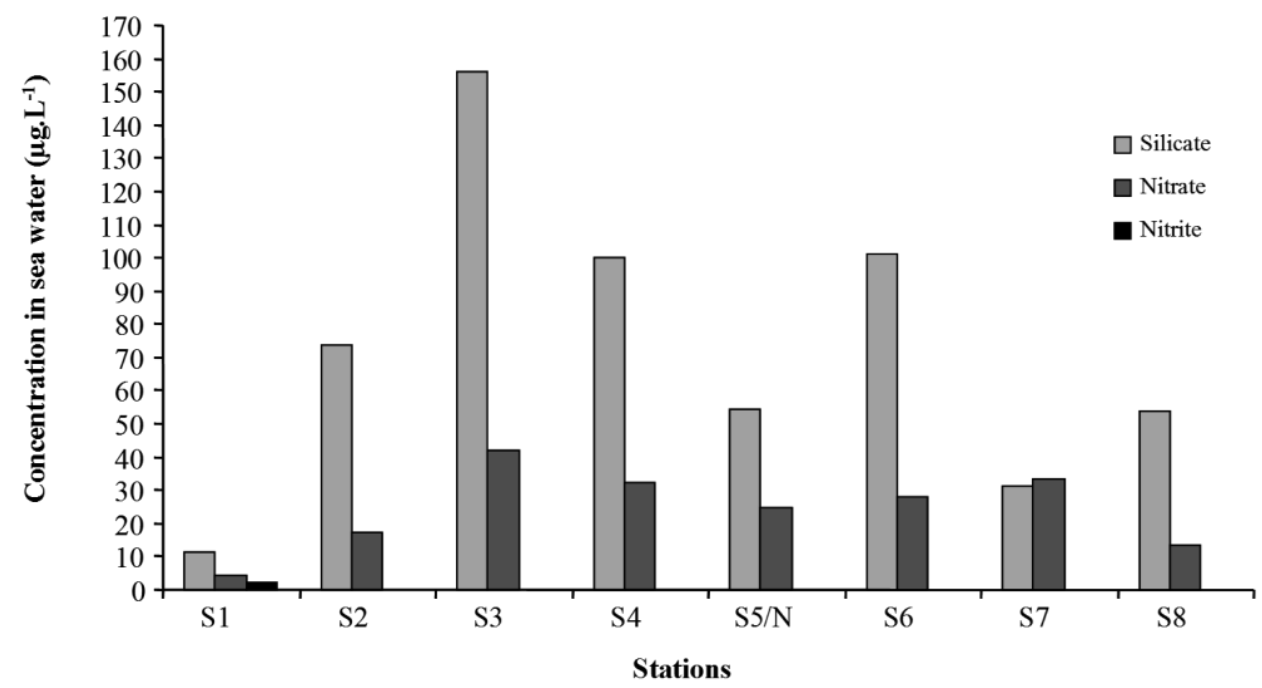

Figure 3. Nutrients concentration measured in all stations.

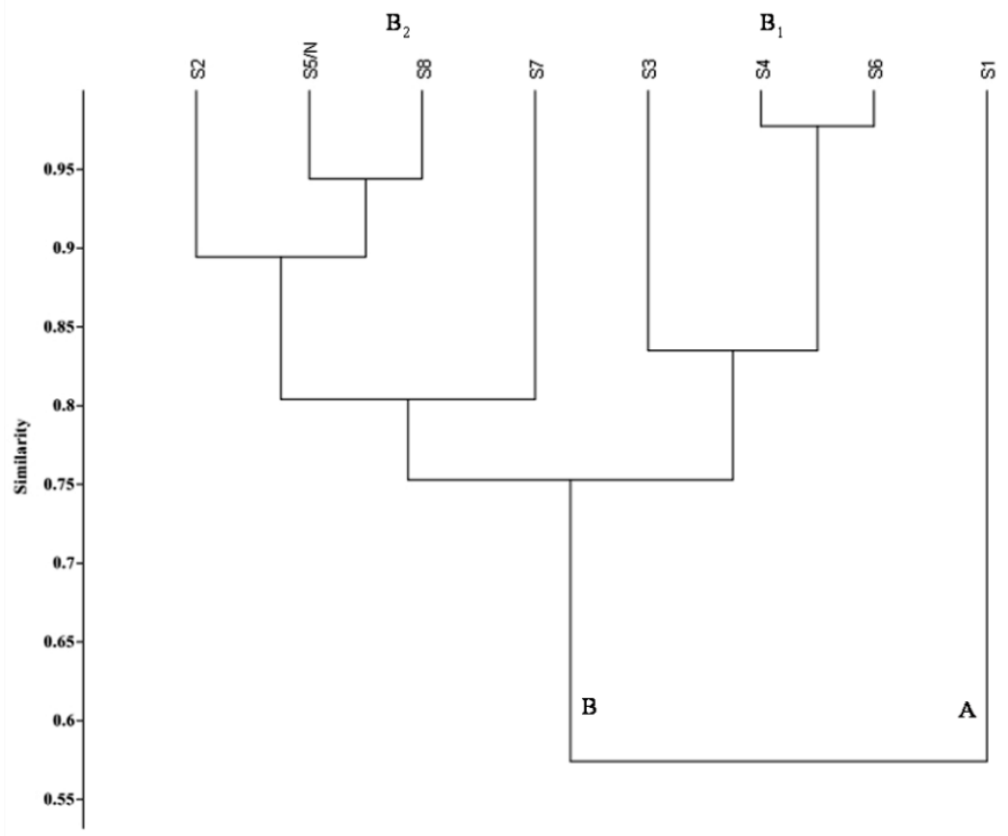

Figure 4. Similarity among stations base on the environmental parameters. 


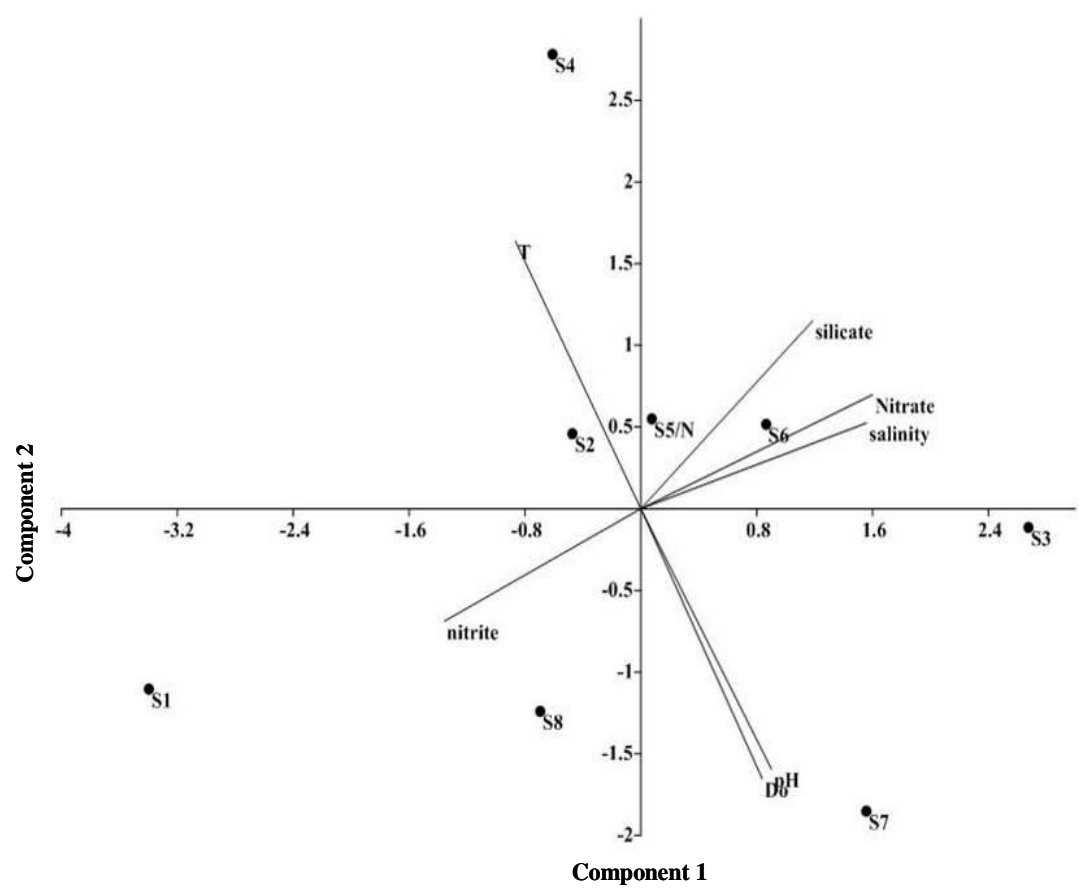

Figure 5. Principal Components Analysis of environmental parameters in all stations.

Table 2. Average of abundance $( \pm S D)$ of identified zooplanktons in each of the 8 stations

\begin{tabular}{cccccccccc} 
& $\mathrm{S}_{1}$ & $\mathrm{~S}_{2}$ & $\mathrm{~S}_{3}$ & $\mathrm{~S}_{4}$ & $\mathrm{~S}_{5 / \mathrm{N}}$ & $\mathrm{S}_{6}$ & $\mathrm{~S}_{7}$ & $\mathrm{~S}_{8}$ \\
& & & & & & & & \\
Acartia tonsa & $830 \pm 87$ & $448 \pm 114$ & $382 \pm 85$ & $255 \pm 43$ & $1545 \pm 181$ & $321 \pm 59$ & $189 \pm 127$ & $106 \pm 42$ \\
Nauplius of A. tonsa & $566 \pm 85$ & $531 \pm 94$ & $262 \pm 33$ & $120 \pm 44$ & $1168 \pm 232$ & $207 \pm 91$ & $160 \pm 43$ & $99 \pm 44$ \\
Nauplius of Balanus improvisus & $113 \pm 28$ & $153 \pm 54$ & 0 & $85 \pm 57$ & $307 \pm 54$ & $104 \pm 43$ & 0 & $78 \pm 44$ \\
Asplanchna priodonta & $500 \pm 156$ & 0 & 0 & 0 & $495 \pm 142$ & 0 & 0 & 0 \\
Nereis diversicolor & $141 \pm 57$ & 0 & 0 & 0 & 0 & 0 & 0 & 0 \\
Podon polyphemoides & 0 & 0 & 0 & 0 & $165 \pm 74$ & $151 \pm 71$ & $123 \pm 43$ & $71 \pm 33$ \\
Lamellibrach larvae & $293 \pm 43$ & $708 \pm 93$ & $248 \pm 33$ & $219 \pm 74$ & $318 \pm 71$ & $368 \pm 113$ & $198 \pm 57$ & 0 \\
Cypris of B. improvisus & $160 \pm 91$ & $189 \pm 74$ & $99 \pm 44$ & $64 \pm 22$ & $260 \pm 90$ & $160 \pm 59$ & 0 & 0 \\
$\quad$ Fish larvae & 0 & $106 \pm 35$ & 0 & 0 & 0 & 0 & 0 & 0 \\
Cirrus Stage of B. improvisus & 0 & 0 & 0 & 0 & 0 & $95 \pm 43$ & 0 & $85 \pm 21$ \\
\hline
\end{tabular}

stations, $\mathrm{S}_{5 / \mathrm{N}}$ has the highest abundance of total zooplanktons $\left(426 \pm 524\right.$ ind. $\left.\mathrm{m}^{-3}\right)$ and $\mathrm{S}_{8}$ has the lowest abundance of total zooplanktons $\left(43 \pm 48\right.$ ind. $\left.\mathrm{m}^{-3}\right)$.

According to the one-way ANOVA and Post Hoc Tukey's test, significant differences were observed $(P<0.05)$ in the abundance of zooplanktons among the stations. Also, there was significant correlation between abundance of some of the zooplanktons and environmental parameters. Nauplius of $B$. improvisus had significant correlation with temperature $(P<0.01)$. Cirrus stage of $B$. improvisus showed significant correlation with $\mathrm{DO}(\mathrm{P}<0.05)$. Significant correlation was also found between $A$. priodonta and silicate $(P<0.05)$. Nereis diversicolor had significant correlation with silicate, nitrate $(P<0.05)$ and nitrite, salinity $(P<0.01)$. $P$. polyphemoides significantly correlated to DO $(\mathrm{P}<0.01)$ and salinity $(\mathrm{P}<0.05)$. Fish larvae and Lamellibranch larvae showed significant correlation with $\mathrm{DO} P<0.05$ and $\mathrm{P}<0.01$, respectively, (Table 3 ).

Acartia tonsa has the highest total abundance $\left(509 \pm 472\right.$ ind. $\left.\mathrm{m}^{-3}\right)$ of all zooplanktons, followed by Nauplius of $A$. tonsa $\left(389 \pm 362\right.$ ind. $\left.\mathrm{m}^{-3}\right)$ and Lamellibranch larvae $\left(294 \pm 200\right.$ ind $\left.\mathrm{m}^{-3}\right)$. Fish larvae have the lowest total abundance $\left(13 \pm 37\right.$ ind. $\left.\mathrm{m}^{-3}\right)$. Abundance percentages of zooplanktonic groupd are shown in Figure 6. So, Copepoda has the highest percentage of abundance (53\%) followed by Lamellibranch larvae and Cirripedia (18 and 15\%, respectively). The lowest percentages belong to Polychaeta (Nereididae) and fish larvae (1\%). Distribution types of zooplanktons are 
shown in (Table 4). Half of zooplanktons had uniform and other had spotty distribution in stations.

Acartia tonsa has the highest amount of biomass $\left(80 \mathrm{mg} \cdot \mathrm{m}^{-3}\right)$ followed by fish larvae $\left(37 \mathrm{mg} \cdot \mathrm{m}^{-3}\right)$. The lowest amount of biomass belong to Nauplius of $B$. improvises and $N$. diversicolor $\left(0.41\right.$ and $0.44 \mathrm{mg} \cdot \mathrm{m}^{-3}$ respectively). The highest percentage of biomass among all zooplanktonic groups belongs to Copepoda (63\%) and followed by fish larvae (27\%). Also, Polychaeta ( $N$. diversicolor) has the lowest percentage of biomass among all groups (0.3\%) (Figure 7 ).

\section{Discussion}

In this study the abundance, biomass and species composition of zooplankton in the southern part of Caspian Sea were investigated. The last station $\left(\mathrm{S}_{8}\right)$ was very close to border of south and middle Caspian. Based on our results, abundance of zooplankton significantly correlated with the physico-chemical parameters of water, except in case of $\mathrm{pH}$. While, these correlations were not found for copepods, and they did not show significant correlation with any of measured parameters. Parts of Our results obtained in this study are congruent with the observation made by Coman et al., (2003) reporting the lack of correlation between water quality and zooplankton abundance observed. While, Lubzens et al., (1993) found significant correlation between salinity, temperature, DO and the abundance of rotifers. In this study 7 species of zooplankton belong to 7 families were identified. These species either including both Holo and meroplanktons. For the Caspian Sea, studies regarding to the composition and diversity of the plankton where made (Rowshantabari et al., 2003; Bagheri et al., 2010; Bagheri et al., 2013) reporting a maximum of 55 species including: 9 copepods, 6 rotifers, 5 protozoans and 29 cladocerans. Rowshantabari et al., (2012) reported 14 species of zooplankton. Later Rowshantabari et al., (2014) reported 22 species of zooplankton in the southern of Caspian Sea, including 4 copepods, 9 rotifers, 2 protozoans and 7 cladocerans, both studies made at the south of the Caspian Sea. Comparing this study results with the previous antecedents, the

Table 3. Relationship among zooplankton abundance and environmental parameters

\begin{tabular}{|c|c|c|c|c|c|c|c|}
\hline & Silicate & Nitrate & Nitrite & DO & Salinity & Temperature & pH \\
\hline Acartia tonsa & -0.266 & -0.148 & -0.193 & -0.149 & 0.068 & 0.374 & -0.119 \\
\hline Nauplius of $A$. tonsa & -0.242 & -0.214 & 0.193 & -0.165 & 0.062 & 0.317 & -0.048 \\
\hline Nauplius of Balanus improvisus & -0.215 & -0.172 & 0.061 & -0.256 & -0.032 & $0.546^{* *}$ & -0.268 \\
\hline Cypris of B. improvisus & 0.020 & 0.022 & 0.115 & -0.344 & 0.127 & 0.263 & -0.157 \\
\hline Cirrus stage of $B$. improvisus & 0.082 & -0.120 & -0.162 & $0.432^{*}$ & -0.129 & -0.258 & -0.289 \\
\hline Asplanchna priodonta & $-0.504^{*}$ & -0.301 & 0.525 & -0.128 & -0.282 & 0.321 & -0.115 \\
\hline Nereis diversicolor & $-0.463^{*}$ & $-0.415^{*}$ & $0.939^{* *}$ & -0.234 & $-0.622^{* *}$ & 0.028 & -0.065 \\
\hline Podon polyphemoides & -0.156 & 0.094 & -0.248 & $0.551^{* *}$ & $0.417^{*}$ & -0.074 & 0.144 \\
\hline Fish larvae & 0.020 & -0.165 & -0.108 & $-0.418^{*}$ & -0.068 & 0.033 & -0.006 \\
\hline Lamellibranch larvae & 0.096 & 0.009 & 0.015 & $0.516^{* *}$ & 0.187 & 0.089 & -0.101 \\
\hline
\end{tabular}

** Correlation is Significant at the 0.01 level $(\mathrm{P}<0.01)$

* Correlation is Significant at the 0.05 level $(\mathrm{P}<0.05)$

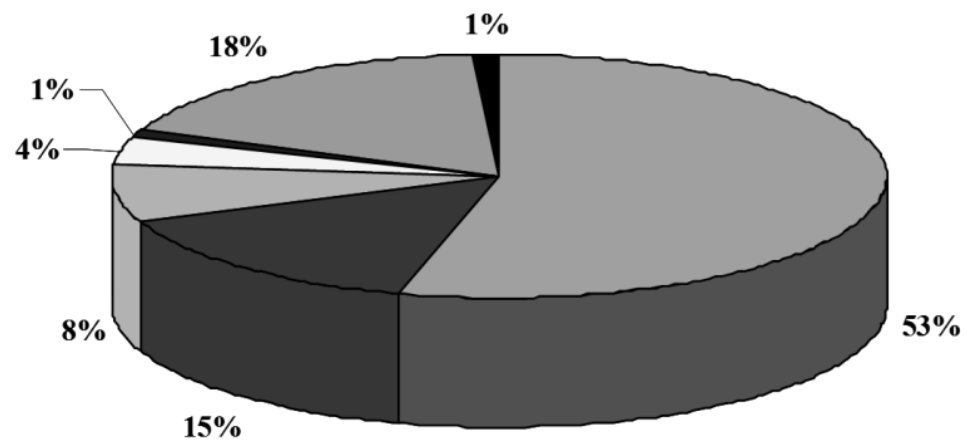

$\square$ Copepoda

$\square$ Cirripedia

$\square$ Rotifera

$\square$ Cladocera

- Fish larvae

$\square$ Lamellibranch larvae

polychaeta

Figure 6. Percentage of abundance of zooplanktonic groups in all stations. 
Table 4. Type of Distribution of identified zooplanktons in all stations

\begin{tabular}{cccc|} 
Zooplanktons & $\begin{array}{c}\text { Mean } \\
\text { abundance }\end{array}$ & $\begin{array}{c}\text { Distribution } \\
\text { index }\end{array}$ & Type of distribution \\
$\begin{array}{c}\text { Acartia tonsa } \\
\text { Nauplius of } \text { A. tonsa }\end{array}$ & $310 \pm 459$ & 414 & Uniform \\
Nauplius of Balanus improvisus & $105 \pm 99$ & 325 & Uniform \\
Asplanchna priodonta & $124 \pm 229$ & 94 & Uniform \\
Nereis diversicolor & $18 \pm 51$ & 142 & Spotty \\
Podon polyphemoides & $64 \pm 78$ & 95 & Spotty \\
Lamellibranch larvae & $294 \pm 200$ & 136 & Spotty \\
Cypris of B. improvisus & $116 \pm 101$ & 87 & Uniform \\
Fish larvae & $13 \pm 37$ & 136 & Uniform \\
Cirrus of B. improvisus & $22 \pm 43$ & 82 & Spotty \\
\end{tabular}

Figure 7. Percentage of biomass of each zooplanktonic group in all stations

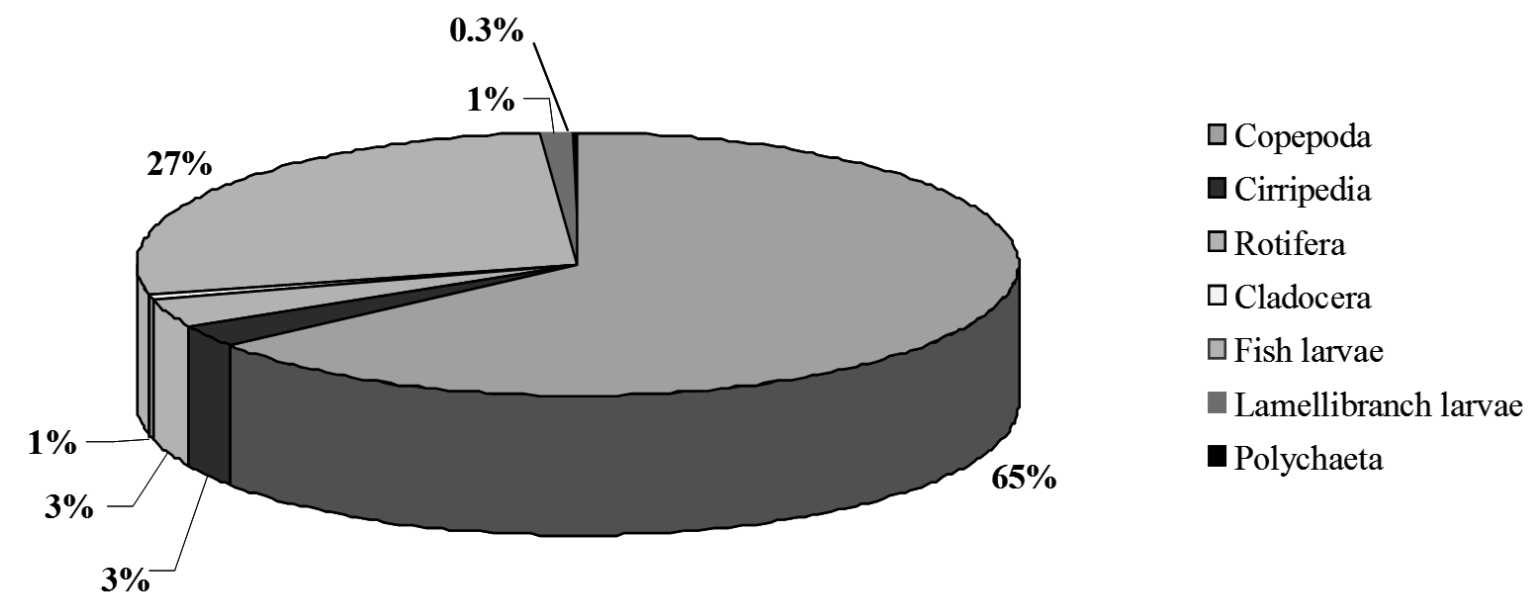

richness here obtained are less. It seems that the diversity of zooplanktons have decreased after invasion of $M$. leidyi according to the previous suggestion made by Rowshantabari et al., (2007); Roohi et al., (2010) and Hosseini et al., (2011) mentioning that zooplankton diversity had decreased considerably after the invasion of M. leidyi into the Caspian Sea from late 80s. M. leidyi is an active predator of zooplankton and fish larvae to an extent that could deplete zooplankton biomass if their populations increase abnormally (Mayer, 1912; Herman et al., 1968; Rowshantabari et al., 2007). Invasive species also have an effect on the appearance or disappearance of some zooplankton species (Shiganova et al., 2001). So, presence of some species had greatly been affected by the biomass and abundance fluctuations of this invasive Ctenophore (Shiganova et al., 2001). As mentioned in results, $A$. tons $a$ had the highest abundance and biomass in winter. Rowshantabari (2000) had stated that, in 1996, A. tonsa was dominant in summer and autumn but Eurytemora grimmi and E. minor that have not seen in our study were dominant in copepod population in spring and winter. Since $1982, A$. tonsa has been transferred to Caspian Sea (Kurashova and Abdullaeva, 1984) and since then its population has grown sharply after 1985 . Today, A. tonsa is the major and dominant zooplankton in the Caspian Sea (Rowshantabari et al., 2012). Before entrance of $A$. tonsa in the south Caspian Sea, Calanipeda aquae-dulcis was dominant (Yelizarenko, 1992). This species lives at the surface layers and its abundance was 1329 ind. $\mathrm{m}^{-3}$ in winter 1996 (Rowshantabari, 2000). After introduction of M. leidyi, their population disappeared in south Caspian Sea. In this study, copepods constituted the dominant population of zooplankton with $53 \%$ of total zooplankton abundance. However, in other studies (Omori \& Ikeda, 1984; Mauchline, 1998; Rowshantabari, 2000 ) they constituted about $88 \%$ in spring, $99 \%$ in summer and autumn and $31 \%$ in winter of the whole zooplankton population. $A$. tonsa, the dominant species of copepods, dominated other species and reached at its maximum value in summer. Within rotifers, only $A$. priodonta was seen. It constituted about $8 \%$ of whole zooplankton population. A. priodonta is a cosmopolitan 
rotifer and is one of the biggest planktonic predators and it feeds on Cyanobacteria, diatoms, dinoflagellates and protozoans and both as grazer and predator (Pociecha \& Wilk-Woźniak 2008). Also, it feeds on other rotifers, such as Keratella and cladocerans (Kappes et al., 2000). Among cladocera, only P. polyphemoides was found. Also, in a study on Impact of a new invasive ctenophore ( $M$. leidyi) on the zooplankton community of Southern Caspian Sea made by Roohi et al., (2008) only the cladocera $P$. polyphemoides was found. In 1996 the maximum number of species among the zooplankton belonged to cladocera, but the representation of this group decreased drastically to only one species, following $M$. leidyi invasion. $P$. polyphemoides exist in surface layers (Manolova, 1964). Rowshantabari et al., (2014) found the highest density of $P$. polyphemoides in spring with a decrease in summer and autumn ( 1 ind $\mathrm{m}^{-3}$ ) and again increased towards the winter. Within cirripedia three larval stage of $B$. improvisus were found. Among them, cypris stage had the highest abundance. Two larval stages (nauplius and cypris) had reported before (Bagheri et al., 2013) but, cirrus stage had not been reported previously in the southern part of Caspian Sea.

\section{Conclusions}

The Caspian Sea is an enclosed water body that plays an important geopolitical role in the central Asia region. The Caspian Sea is under intense pressure from environmental threats such as changes in sea water level, allowed excessive fishing, risk striker marine, infested industries and agriculture as well as developing the urban of most of the Caspian countries (Karrari et al. 2012; Jamalomidi, 2013). Additionally, a novel type of anthropogenic impact that became widespread across the world in recent years, started to affect the Caspian Sea, viz. invasions by undesirable alien species of animals and plants (Shiganova et al., 2004). Mnemiopsis leidyi is a highly fecund comb jelly feeding extensively on zooplankton (Kideys et al., 2008). The impact of the introduced ctenophore M. leidyi (Ivanov et al., 2000) has been tremendous on the Caspian ecosystem causing sharp decreases in zooplankton levels, pelagic fish stocks and other higher components of the ecosystem (Shiganova et al., 2001; Kideys, 2002). It seems that after invasion of $M$. leidyi, composition and abundance of zooplankton in south Caspian Sea waters greatly changed. Some of the species have been vanished from ecosystem and some others have been dominant. Generally, invasive ctenophore deeply affected on planktonic community and ultimately on total food chain of Caspian Sea. Due to the high importance of zooplankton in the food chain, studying the abundance and diversity of them in southern part of Caspian Sea is useful for better management of fish stocks and other aspects of the sea.

\section{Acknowledgements}

This study was part of the biological and hydrochemical studies of "Caspian Sea environmental monitoring" founded and supported by Iranian National Institute for Oceanography and Atmospheric Science (INIOAS). The author appreciates colleagues Mirmahmoud Seyedvalizadeh and Nasser Ghesemi for their help in field measurements.

\section{References}

Aladin, N.V., \& Plotnikov, I.S. (2004). The Caspian Sea. Lake Basin management initiative. Thematic Paper. Moscow, Russia.

APHA. (1985). Standard Methods for the Examination of Water and Wastewater. (16th ed). Washington, USA.

Bagheri, S., Mashhor, M., Wan Maznah, W. O., \& Negarestan, H. (2010). Distribution of Mnemiopsis leidyi and zooplankton in the south-western Caspian Sea, 2008. International Offshore and polar engineering Conference (pp.20-25). Beijing, China.

Bagheri, S., Sabkara, J., Mirzajani, A., Khodaparast, S.H., Yosefzad, E., \& Yeok, F.S. (2013). List of Zooplankton Taxa in the Caspian Sea Waters of Iran. Journal of Marine Biology, 1-7. http:// doi.org/10.1155/2013/134263.

Birshtein, Y.A., Vinogradov, L.G., Kondakova, N.N., Koun, M.S., Astakhva, T.V., \& Ramanova, N.N. (1968). Atlas of invertebrates in the Caspian Sea. Moskow, Russia, 413 pp.

Coman, F.E., Connolly, R.M., \& Preston, N.P. (2003). Zooplankton and epibenthic fauna in shrimp ponds: factors influencing assemblage dynamics. Aquaculture Research, 34, 359-371.

Dumont, H. J. (1995). Ecocide in the Caspian. Nature, 673-674.

Fuentes, V. L., Angel, D. L., Bayha, K. M., Atienza, D., Edelist, D., Bordehore, C., Gili, J. M., \& Purcell, J. E. (2010). Blooms of the invasive ctenophore, Mnemiopsis leidyi, span the Mediterranean Sea in 2009. Hydrobiologia, 645(1), 2337. http://doi.org/10.1007/s10750-010-0205-z.

Guangjun, L.V. (2013). Structure and diversity of zooplankton communities in four reservoirs with varying nutrient compositions in the Yangtze River Basin, International Conference on Remote Sensing, Environment and Transportation Engineering (pp. 566-572). Nanjing, China.

Hashemian, A., Rowshantabari, M., Roohi, A., Makhlogh, A., Ganjyan, A., Tahami, F., \&

Herman, S. S., Mihursky, J. A., \& McErlean, A. J. (1968). Zooplankton and environmental characteristics of the Patuxent estuary. Chesapeake Science, 9, 67-82.

Hosseini, S. A., Ganjyan, A., Makhlogh, A., Keyhansani, A., Tahami, F., Mohamadjani T., Makaremi, M., \& Rowshantabari, M. (2011). Hydrology and hydrobiology of southern of Caspian Sea. IFRO, (pp. 1375-1376). (In persian).

Ivanov, P.I., Kamakin. A., Ushivtzev. V., Shiganova, T., Zhukova, O., Aladin, N., Wilson, S., Harbison, G., \& Dumont, H. (2000). Invasion of Caspian Sea by the comb jelly fish Mnemiopsisleidyi (Ctenophora). Biological Invasions, 2, 255-258.

Jamalomidi, M. (2013). Temporal changes of surface chlorophyll in south of Caspian Sea based on data gained 
by MODIS of Aqua satellite. International Journal of Agriculture and Crop Sciences, 1269-1275.

Kappes, H., Mechenich, C., \& Sinsch, U. (2000). Long-term dynamics of Asplanchna priodonta in Lake Windsborn with comments on the diet. Hydrobiologia, 432, 91-100. http://doi.org/ 10.1023/A:1004022020346.

Karrari, P., Mehrpour, O., \& Abdollahi, M. (2012). A systematic review on status of lead pollution and toxicity in Iran; Guidance for preventive measures. DARU Journal of Pharmaceutical Sciences, 1-17.

Kideys, A.E. (2002). Fall and rise of the Black Sea ecosystem. Science, 297, 1482-1484.

Kideys, A.E., Roohi, A., Eker, E., Melin, F., \& Beare, D. (2008). Increased chlorophyll a level in the southern Caspian Sea, following an invasion of jellyfish. Research Letters in Ecology, 1-4. http:// doi.org/10.1155/2008/185642.

Kosarev, A., \& Yablonskaya, E.A. (1994). The Caspian Sea. In the Haque, Academic publishing.

Kurashova, E. K., \& Abdullaeva, N.M. (1984). Acartia clause Giesbrecht (Calanoidae, Acartiidae) in Caspian Sea. Zoological, 63(6), 931-933.

Kusmorskaya, A.P. (1964). Zooplankton in the North Caspian Sea. In Ecology of invertebrates in the South Seas of the USSR (pp.94-147).

Kuticova, L.A. (1970). Rotatoria. Moscow, Leningrad, 744pp.

Laloei, F., Rowshantabari, M., Roohi, A., Takmilian, K., Ganjyan, A., Makhlogh, A., \& Lubzens, E., Wax, Y., Minko, G., \& Adler, F. (1993). A model evaluating the contribution of environmental factors to the production of resting eggs in the rotifer Brachionus plicatilis. Hydrobiologia, 256, 127-138.

Mamaev, V. (2002). The Caspian Sea-enclosed and with many endemic species. European Environment Agency (EEA) Project Manager, Anita Künitzer (Final edition), pp: 1-26.

Manolova, E. Q. (1964). Cladocerans. Moscow, Leningrad. (In Russian).

Mauchline, J. (1998). The biology of calanoid copepods. Advance in Marine Biology, 33: 710.

Mayer, A. G. (1912). Ctenophores of the Atlantic Coast of North America. Washington, Carnegie Institution of Washington.

Omori, M., \& Ikeda, T. (1984). Methods in Marine Zooplankton Ecology. NewYork, Wiley-Interscience publication.

Petipa, T. S. (1957). On average weight of the main zooplankton forms in the Black Sea. Proc. Sevastopol. Biological Station, 9, 39-57.

Pociecha, A., \& Wilk-Woźniak, E. (2008). Comments on the diet of Asplanchna priodonta (Gosse, 1850) in the Dobczycki dam reservoir on the basis of field sample observations. Oceanological and Hydrobiological Studies, 37(3), 63-69. https://doi.org/10.2478/v10009-008-0004-2.

Pourang, N., Eslami, F., Nasrollahzadeh Saravi, H., \& Fazli, H. (2016). Strong biopollution in the southern Caspian Sea: the comb jelly Mnemiopsis leidyi case study. Biological Invasions, 18(8), 2403-2414. doi:10.1007/s10530-0161171-9

Postel, L., Fock, H., \& Hagen, W. (2000). Biomass and abundance. In Harris, R., Wiebe, P., Lenz, J., Skjoldal, H. R. and Huntley, M. (Eds.), ICES Zooplankton Methodology Manual (pp: 83-192). Academic Press, London.

Richardson, A.J. (2008). In hot water: zooplankton and climate change. ICES Journal of Marine Science, 65(3), 279-295. http://doi.org/ 10.1093/icesjms/fsn028.

Rodionov, S. N. (1994). Global and Regional Climate Interaction: The Caspian Sea Experience. Netherlands, Kluwer Academic Publishing.
Roohi, A., Zulfigar, Y., Kideys, A., Aileen, T., Ganjian, A., \& EkerDeveli, E. (2008). Impact of a new invader ctenophore Mnemiopsis leidyi on the zooplankton of the southern Caspian Sea, Marine Ecology, 29 (4), 421-434. http://doi.org/ 10.1111/j.1439-0485.2008.00254.x.

Roohi, A., Kideys, A. E., Sajjadi, A., Hashemian, A., Pourgholam, R., Fazli, H., Khanari, A. G., \& Eker, E. (2010). Changes in biodiversity of phytoplankton, zooplankton, fishes and macrobenthos in the Southern Caspian Sea after the invasion of the ctenophore Mnemiopsis leidyi. Biological Invasions, 12, 2343-2361. http://doi.org/ 10.1007/s10530-009-9648-4.

Rowshantabari, M. (2000). Distribution of zooplankton in the southern of Caspian Sea (Copepods: order) (B. C thesis). TarbiatModaress University, Tehran, Iran. (In Persian).

Rowshantabari, M., Takmilian, K., Sabkara, J., Roohi, A., \& Rostamian, M. T. (2003). Distribution of zooplankton in the southern of Caspian Sea. Iranian Scientific Fisheries Journal, 12(3), 83-96. (In Persian).

Rowshantabari, M., Nejatkhah, P., Hoseini, S. A., Khodaparast, N., \& Rostamian, M. T. (2007). Diversity, abundance and distribution of zooplankton in the southern of Caspian Sea in winter 1384 and comparison with previous years. Journal of Environmental Sciences and Technology, 9(4), 129-137. (In Persian).

Rowshantabari, M., Rahmati, R., Khodaparast, N., Rezvani, R., Eslami, F., Soleimaniroudi, A., Keyhansani, A., Kanani, M. R., \& Amani, Gh. (2012). The survey of diversity, distribution and abundance of zooplankton in the southern of Caspian Sea (Final Report). Mazandaran, Iran, Caspian Sea Ecology Research Center, (In Persian).

Rowshantabari, M., Fatemi, S. M. R., Pourgholam, R., \& Mousavi- Nadoushan, R. (2014). Latest Diversity Trend and Seasonal Abundance of Population of Zooplankton (Holoplankton) Communities in the South Caspian Sea, Iran. Iranian Journal of Fisheries Sciences, 13(2), 437-448.

Salmanov M.A. (1999). Ecology and Biological Productivity of the Caspian Sea. Baku, Azerbaijan, Institute of Zoology.

Shiganova, T. A. (1993). Ctenophore Mnemiopsis leidyi and ichthyoplankton in the Sea of Marmara in October of 1992. Oceanology, 33, 900-903.

Shiganova, T., Mirzoyan, Z., Studenikina, E., Volovik, S., SiokouFrangou, I., Zervoudaki, S., Christou, E., Skirta, A., \& Dumont, H. (2001). Population development of the invader ctenophore Mnemiopsis leidyi, in the Black Sea and in other seas of the Mediterranean basin. Marine Biology, 139, 431-445. http://doi.org/ 10.1007/s002270100554.

Shiganova, T.A., Dumont, H.J., Sokolsky, A.F., Kamakin, A.M., Tinenkova, D., \& Kurasheva, E.K. (2004). Population dynamics of Mnemiopsis leidyi in the Caspian Sea, and effects on the Caspian ecosystem. In Dumont, H., Shiganova, T.A., \& Niermann, U (Eds.), Aquatic Invasions in the Black, Caspian, and Mediterranean Seas, $(35,71-$ 111). Kluwer, Dordrecht.

Sipkay, C., Kiss, K.T., Vadadi-Fülöp, C., \& Hufnagel, L. (2009). Trends in research on the possible effects of climate change concerning aquatic ecosystems with special emphasis on the modeling approach. Applied Ecology and Environmental Research, 17(2), 171-198.

Yelizarenko, M. M. (1992). Feeding of kilka in the Middle Caspian during the summer season. In Biological resources of the Caspian Sea. Abstracts of the 1st International Conference, September 1992 (pp. 111113). Astrakhan, Russia. (In Russian). 